\title{
GNRH2 wt Allele
}

National Cancer Institute

\section{Source}

National Cancer Institute. GNRH2 wt Allele. NCI Thesaurus. Code C52419.

Human GNRH2 wild-type allele is located in the vicinity of 20p13 and is approximately 2 $\mathrm{kb}$ in length. This allele, which encodes progonadoliberin-2 protein, is involved in the regulation of reproduction in females. 